\title{
Single electron transfer by an extracellular laccase from the white-rot fungus Pleurotus ostreatus
}

\author{
Hong-Duk Youn, Kyu-Jung Kim, † Jin-Soo Maeng, Young-Hoon Han, \\ In-Beom Jeong, Gajin Jeong, Sa-Ouk Kang and Yung Chil Hah
}

\author{
Author for correspondence: Sa-Ouk Kang. Tel: +82 2880 6703. Fax: +82 28884911 \\ e-mail: kangsaou@alliant.snu.ac.kr
}

Department of

Microbiology, College of Natural Sciences, and

Research Center for Molecular Microbiology, Seoul National University, Seoul 151-742, Republic of Korea

\begin{abstract}
Two different bands with laccase activity were obtained after nondenaturing PAGE of the culture filtrate of Pleurotus ostreatus. Immunoblot analysis revealed that antisera raised against laccase I were not reactive to laccase II. Laccase I, which exhibited faster mobility on nondenaturing polyacrylamide gel, was purified $42 \cdot 9$-fold with an overall yield of $10.8 \%$. Gel filtration and SDS-PAGE revealed that laccase $I$ is a single polypeptide with a molecular mass of approximately $64 \mathrm{kDa}$. Laccase I contained $12.5 \%$ carbohydrate by weight and 3.9 mol copper (mol protein) ${ }^{-1}$. The absorption spectrum of laccase I showed a type 1 signal at $605 \mathrm{~nm}$ and EPR spectra showed that the parameters of the type 1 and type 2 Cu signals were $g_{\|}=2.197$ and $A_{\|}=0.009 \mathrm{~cm}^{-1}$, and $g_{\|}=2.263$ and $A_{\|}=0.0176 \mathrm{~cm}^{-1}$, respectively. The data obtained from the $\mathrm{pH}$ profiles suggested that two ionization groups, whose $\mathrm{p} K_{\mathrm{a}}$ values were $5.60-5.70$ and 6.70-6.85, may play an important role in the active site of laccase $I$ as the ligand of copper metal. The optimal pH and temperature for the activity of laccase I were 6.0-6.5 and 30-35 ${ }^{\circ} \mathrm{C}$, respectively. The enzyme had affinity for various lignin-related phenolic compounds: the $K_{m}$ values for ferulic acid and syringic acid were 48 and $89 \mu \mathrm{M}$, respectively. EPR spectroscopic study of the action of laccase I on 3,5-dimethoxy-5-hydroxyacetophenone indicated that this enzyme catalyses single electron transfer with the formation of the phenoxy radical as an intermediate.
\end{abstract}

Keywords: Pleurotus ostreatus, laccase, single electron transfer, phenoxy radical

\section{INTRODUCTION}

Lignin is a structurally amorphous, aromatic biopolymer found abundantly in woody plants and extremely resistant to microbial attack in nature, but white-rot fungi are able to degrade it efficiently. Lignin degradation by white-rot basidiomycetes is considered to be a nonspecific, oxidative process achieved by the action of either peroxidase, which depends on hydrogen peroxide, or laccase, which depends on oxygen molecules (Kirk \& Farrell, 1987). The ability of fungal laccases to oxidize lignin-related phenolic compounds suggests that these enzymes play a role in lignin degradation (Eriksson $e t$ al., 1990). Laccases have been isolated from various fungi and their physiological functions have been discussed (Froehner \& Eriksson, 1974; Wood, 1980; De Vries $e t$ al., 1986; Niku-Paavola $e t$

†Present address: Department of Biology, College of Sciences, Kangreung National University, Republic of Korea. al., 1988; Rehman \& Thurston, 1992; Jeong et al., 1992). The white-rot fungus Pleurotus ostreatus is a well-known lignin-degrader (Agosin et al., 1985) and it can produce various enzymes, such as extracellular peroxidase (Kang $e t$ al., 1993), veratryl alcohol oxidase (Sannia et al., 1991), glucose oxidase (Shin et al., 1993) and laccase (Sannia et al., 1986; Kim et al., 1987), all of which are related to lignin degradation.

In the present paper, we report the further physicochemical properties of one of two immunologically different laccases from the culture filtrate of $P$. ostreatus.

\section{METHODS}

Micro-organism and growth conditions. $P$. ostreatus NFFA 4501, obtained from the Korean Forest Research Laboratory, was used as the source of laccase I for purification. The organism was cultured in shaken, $500 \mathrm{ml}$ Erlenmeyer flasks containing $200 \mathrm{ml}$ complex medium [1\% (w/v) glucose, $0.5 \%$ 
peptone, $0.5 \%$ yeast extract, $1 \%(\mathrm{w} / \mathrm{v})$ malt extract] at $28{ }^{\circ} \mathrm{C}$ for $6 \mathrm{~d}$. For the induction of the enzyme, ferulic acid was added to a final concentration of $1 \mathrm{mM}$ after 2 d culture (Kim et al., 1986).

Chemicals. DEAE Sephadex A-50, Sephacryl S-200HR and syringaldazine were purchased from Sigma, ascorbate oxidase and molecular mass markers for gel filtraticn chromatography and SDS-PAGE from Boehringer Mannheim, and Protein-Pak DEAE 5PW column from Waters. All other reagents used were of the highest quality generally available.

Enzyme assays. Laccase activity was determined by measuring the increase in $A_{530}$ using syringaldazine as substrate at room temperature (Leonowicz \& Grzywnowicz, 1981). One unit of enzyme activity was defined as the amount of enzyme producing $1 \mu \mathrm{mol}$ reaction product $\mathrm{min}^{-1}$. For kinetic studies, enzyme activity was determined by measurement of oxygen consumption with a Clark oxygen electrode (Yellow Springs Instrument). After nondenaturing PAGE, laccase activity was visualized by incubation with $50 \mu \mathrm{M}$ syringaldazine in $50 \mathrm{mM}$ sodium acetate buffer ( $\mathrm{pH} 5 \cdot 5$ ) and fixing with $10 \%(\mathrm{v} / \mathrm{v})$ glacial acetic acid.

Enzyme purification. All purification steps were performed at $4{ }^{\circ} \mathrm{C}$. The culture suspension used for enzyme purification was filtered through Whatman no. 1 filter paper. Solid ammonium sulphate was added to the supernatant to $80 \%$ saturation. The precipitate was collected by centrifugation and dissolved in $20 \mathrm{mM}$ sodium phosphate buffer ( $\mathrm{pH} 7 \cdot 0$ ). Protamine sulphate was added to a final concentration of $1 \%(\mathrm{w} / \mathrm{v}$ ) to remove brownish pigments. The precipitate was removed by centrifugation and the supernatant was dialysed overnight against the same buffer. The dialysed protein was loaded onto a DEAE Sephadex A-50 column $(4 \times 40 \mathrm{~cm})$ equilibrated with the same buffer. The column was then washed and the protein eluted using a linear concentration gradient of $0-0.8 \mathrm{M} \mathrm{NaCl}$ in the same buffer. Two separate fractions with laccase activity were combined and concentrated using an Amicon YM10 membrane. The concentrated sample was applied to a Sephacryl S-200HR column $(2 \cdot 8 \times 120 \mathrm{~cm})$ equilibrated with $20 \mathrm{mM}$ sodium phosphate buffer ( $\mathrm{pH} 6.0)$. Active fractions were again pooled and concentrated using a YM10 membrane. The concentrated protein was further purified using a Waters Delta Prep 4000 chromatography system. The sample was loaded onto a ProteinPak DEAE 5PW column $(2.15 \times 15 \mathrm{~cm})$ equilibrated with $20 \mathrm{mM}$ sodium phosphate buffer ( $\mathrm{pH} \mathrm{6.0)}$ ). The column was washed with the same buffer and laccase I and II were eluted using a linear concentration gradient of $0.0-0.4 \mathrm{M} \mathrm{NaCl}$ at a flow rate of $5 \mathrm{ml} \mathrm{min}^{-1}$.

Preparation of anti-laccase I antisera. Purified laccase I was subjected to SDS-PAGE. The polypeptide band was cut from the gel and pulverized with a homogenizer. This preparation was used as an immunogen. Each of three mice was initially injected subcutaneously with approximately $15 \mu \mathrm{g}$ laccase I emulsified in Freund's complete adjuvant. Subsequently, approximately $15 \mu \mathrm{g}$ laccase I was injected at 2 -week intervals for 8 weeks.

Immunoblot analysis. SDS-PAGE was performed on a $10 \%$ $(\mathrm{w} / \mathrm{v})$ polyacrylamide gel. Electrotransfer of proteins was carried out according to the method of Towbin et al. (1979). The proteins were electrotransferred to a nitrocellulose membrane for $1 \mathrm{~h}$ at $170 \mathrm{~mA}$ in a Bio-Rad transblot apparatus. Three lanes, containing molecular mass markers, laccase I and II, were cut out and stained with $0.1 \%$ amidoblack and destained until the bands were discernible. The rest of the membrane was blocked by incubation with $0.5 \%$ BSA in TBST [ $10 \mathrm{mM}$ Tris ( $\mathrm{pH} \mathrm{8.0)}$, $150 \mathrm{mM} \mathrm{NaCl}, 0.05 \%$ Tween 20] for $30 \mathrm{~min}$ at room temperature. The membrane was incubated in TBST containing anti-laccase I antiserum at 1:2000 dilution overnight and then washed with TBST for $30 \mathrm{~min}$. It was incubated again in TBST containing anti-mouse IgG (whole molecule) alkaline phosphatase conjugate at $1: 10000$ dilution for $90 \mathrm{~min}$, washed with TBST for $30 \mathrm{~min}$ and developed with nitro blue tetrazolium plus 5-bromo-4-chloro-3-indolyl phosphate in alkaline phosphatase buffer [100 mM Tris (pH 9.5), $100 \mathrm{mM} \mathrm{NaCl}, 5 \mathrm{mM}$ $\left.\mathrm{MgCl}_{2}\right]$.

Molecular mass determination. The molecular mass of the native enzyme was determined by gel filtration chromatography on a Sephacryl S-200 HR column. The column was calibrated with aldolase $(158 \mathrm{kDa})$, albumin $(68 \mathrm{kDa})$, chymotrypsinogen $(25 \mathrm{kDa})$, and cytochrome $c(12.5 \mathrm{kDa})$. SDS-PAGE was performed on a $7.5 \%$ polyacrylamide gel (Laemmli, 1970). As standard markers, $\beta$-galactosidase $(116.4 \mathrm{kDa})$, fructose- 6 -phosphate kinase $(85.2 \mathrm{kDa})$, glutamate dehydrogenase $(55.6 \mathrm{kDa})$, aldolase $(39.2 \mathrm{kDa})$, and triosephosphate isomerase $(26.6 \mathrm{kDa})$ were used.

Determination of the concentrations of protein, carbohydrate and copper. The protein concentration was estimated by the Lowry method using BSA as the standard. The carbohydrate content was determined according to the method of Dubois $e$ al. (1956) using glucose as the standard. The copper content was determined according to the method described by Brumby \& Massey (1967).

Amino-terminal sequence analysis. The amino-terminal sequence of laccase I was determined with a MilliGen/Biosearch 6600 Prosequencer protein sequencing system (Millipore).

Spectroscopic studies. The absorption spectrum of native laccase I was determined in $50 \mathrm{mM}$ sodium acetate buffer $(\mathrm{pH} 5.0)$ at room temperature using a Shimadzu model UV-265 spectrophotometer. EPR spectra of the native enzyme were recorded on a Bruker ESP 300 S EPR spectrometer with modulation amplitude $2 \mathrm{mT}$, microwave power $20 \mathrm{~mW}$ and frequency $9 \cdot 42 \mathrm{GHz}$. Probe temperature was regulated with a nitrogen cryostat equipped with a temperature control unit. Temperature was maintained at approximately $100 \mathrm{~K}$. For the EPR spectroscopic detection of the phenoxy radical, the reaction mixture contained $0.1 \mathrm{M}$ sodium phosphate buffer $(\mathrm{pH} 6.0$ ), $0.5 \mathrm{U}$ laccase I and $1.0 \mathrm{mM}$ 3,5-dimethoxy-5-hydroxyacetophenone. The EPR spectrum of the phenoxy radical was measured at $323 \mathrm{~K}$ with modulation amplitude $50 \mu \mathrm{T}$, microwave power $7.96 \mathrm{~mW}$ and frequency $9.43 \mathrm{GHz}$.

\section{RESULTS AND DISCUSSION}

\section{Purification of laccases}

Two different bands with laccase activity were visualized by nondenaturing PAGE of the culture filtrate of $P$. ostreatus (Fig. 1). Laccase I, which exhibited much faster mobility on nondenaturing polyacrylamide gel, appeared to be the major isozyme. Two isozymes with laccase activity were purified from the culture filtrate as summarized in Table 1 . Laccase I was purified $42 \cdot 9$-fold with a recovery of $10.8 \%$ and laccase II was partially purified 23.9 -fold with a recovery of $1 \cdot 0 \%$. The specific activities of purified laccases I and II were 3.00 and $1.67 \mathrm{U}$

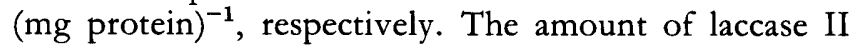
obtained was insufficient for further purification.

\section{Comparison of laccase I and laccase II}

Laccases I and II had distinct mobilities in nondenaturing PAGE (see above). The two laccases were also immunologically different (Fig. 2b): antisera raised against laccase I recognized purified laccase I but not laccase II. However, 
12

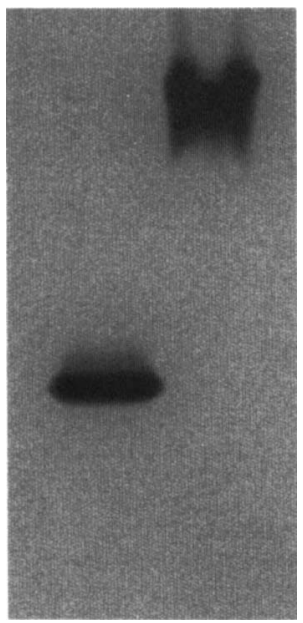

Fig. 1. Nondenaturing PAGE of two laccases from P. ostreatus. The polyacrylamide concentration was $10 \%$. Laccase activity was detected by staining with $50 \mu \mathrm{M}$ syringaldazine in $50 \mathrm{mM}$ sodium acetate buffer (pH 5.5) and fixing with $10 \%$ glacial acetic acid. Lanes: 1 , purified laccase I $(2 \mu \mathrm{g}) ; 2$, partially purified laccase II $(5 \mu \mathrm{g})$.

the apparent molecular masses of these two enzymes were approximately equal in size as determined by $10 \%$ SDSPAGE (approx. $64 \mathrm{kDa}$; Fig. 2a). The molecular mass of laccase I as determined by Sephacryl S-200 HR gel filtration chromatography, was similar to the value estimated by SDS-PAGE, indicating that the enzyme consists of a single polypeptide. Its molecular mass was slightly different from that of the laccase of $P$. ostreatus strain 3004 (approx. $59 \mathrm{kDa}$; Sannia et al., 1986).

The amino-terminal sequence of laccase I was compared with those of other fungal laccases (Fig. 3). It was quite different from that of Neurospora crassa (Germann et al., 1988), but similar to those of other white-rot fungi (Jeong et al., 1992; Sannia et al., 1986; Kosima et al., 1990; Saloheimo et al., 1991). It was however notable that the amino-terminal sequence of laccase I of $P$. ostreatus NFFA (a)

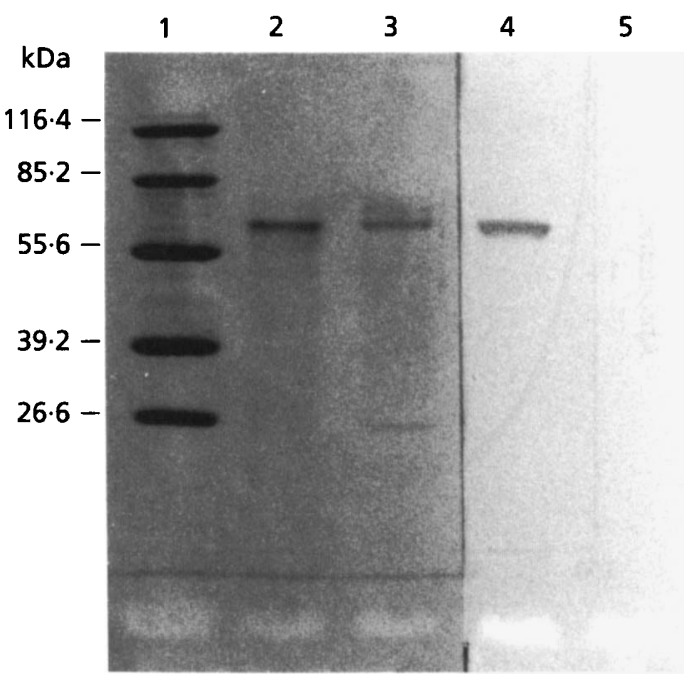

Fig. 2. Electrotransfer of $P$. ostreatus laccases after $10 \%$ SDSPAGE. (a) Protein stain with $0.1 \%$ amidoblack. Lanes: 1, molecular mass markers; 2, purified laccase 1; 3, partially purified laccase II. (b) Immunoblot with anti-laccase I antiserum. Lanes: 4, purified laccase I; 5 , partially purified laccase II.
Pleurotus ostreatus NFFA 4501

Pleurotus ostreatus 3004

Coriolus hirsutus IFO 4917

Lentinus edodes ATCC 48085

Phlebia radiata ATCC 64658

Neurospora crassa FGSC 321
A I G P T G N M Y I V

A I G S G N T Y I V

A I G P T A D L T I S

A I G P T D I $Q I V$

S I G P V T N F H I V

G G G G G C N S P T N
Fig. 3. Amino-terminal sequence comparison between laccase I of $P$. ostreatus NFFA 4501 and those of other fungi: $P$. ostreatus 3004 (Sannia et al., 1986), C. hirsutus (Kosima et al., 1990), L. edodes (Jeong et al., 1992), P. radiata (Saloheimo et al., 1991) and $N$. crassa (Germann et al., 1988).

4501 was slightly different from that of laccase from $P$. ostreatus strain 3004 (Sannia et al., 1986), suggesting that even laccases from the same fungal species may have

Table 1. Purification of extracellular laccases from $P$. ostreatus

\begin{tabular}{|c|c|c|c|c|}
\hline Purification step & $\begin{array}{c}\text { Total } \\
\text { protein } \\
\text { (mg) }\end{array}$ & $\begin{array}{l}\text { Specific } \\
\text { activity } \\
\left(\mathrm{U} \mathrm{mg}^{-1}\right)\end{array}$ & $\begin{array}{c}\text { Recovery } \\
(\%)\end{array}$ & $\begin{array}{c}\text { Purification } \\
\text { (-fold) }\end{array}$ \\
\hline Culture filtrate & $760 \cdot 0$ & 0.07 & $100 \cdot 0$ & $1 \cdot 0$ \\
\hline Ammonium sulphate precipitation & $81 \cdot 0$ & 0.33 & $54 \cdot 0$ & $4 \cdot 7$ \\
\hline Protamine sulphate precipitation & $40 \cdot 0$ & $0 \cdot 37$ & $30 \cdot 0$ & $5 \cdot 3$ \\
\hline DEAE Sephadex A-50 chromatography & $25 \cdot 0$ & $0 \cdot 48$ & $24 \cdot 0$ & $6 \cdot 9$ \\
\hline Sephacryl S-200HR chromatography & $5 \cdot 2$ & $1 \cdot 42$ & $14 \cdot 8$ & $20 \cdot 3$ \\
\hline \multicolumn{5}{|l|}{ Protein-Pak DEAE 5PW chromatography } \\
\hline Laccase I & $1 \cdot 8$ & $3 \cdot 00$ & $10 \cdot 8$ & $42 \cdot 9$ \\
\hline Laccase II & $0 \cdot 3$ & 1.67 & $1 \cdot 0$ & $23 \cdot 9$ \\
\hline
\end{tabular}




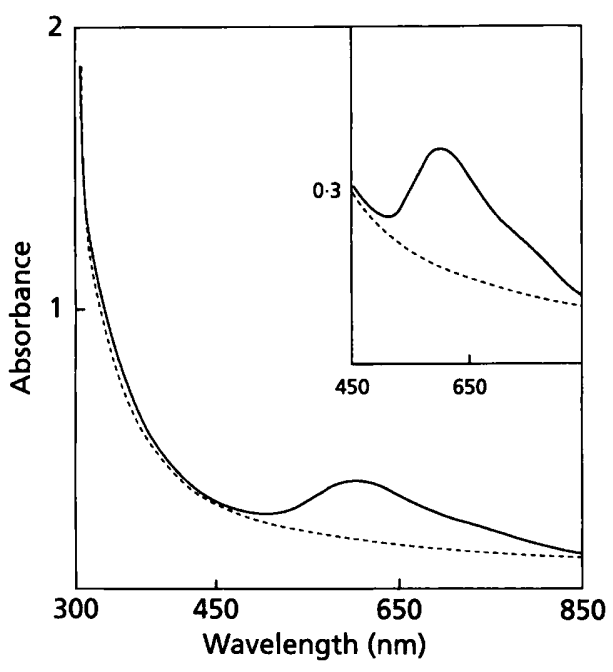

Fig. 4. Absorption spectrum of $P$. ostreatus laccase I. Enzyme samples $(1.4 \mathrm{mg})$ were dissolved in $50 \mathrm{mM}$ sodium acetate buffer (pH 5.0). —_, Native enzyme; ---, enzyme treated anaerobically with ascorbate. The inset shows the enlarged spectrum.

slightly different amino acid sequences which do not alter enzyme activity.

Laccase I was a glycoprotein containing $12.5 \%$ carbohydrate by weight. Most fungal laccases have been reported to contain 10-25\% carbohydrate (Reinhammer, 1984).

\section{Copper as a cofactor}

Laccase I contained approximately $3.9 \mathrm{~mol}$ copper (mol protein $)^{-1}$ as determined by the method described by Brumby \& Massey (1967). Ascorbate oxidase, which contains $8 \mathrm{~mol}$ copper (mol protein) $)^{-1}$ (Mondovi \& Avigliano, 1984), was estimated by this method to contain approximately $7.7 \mathrm{~mol}$ copper (mol protein) $)^{-1}$. The absorption spectrum of laccase $I$ had a type 1 signal at $605 \mathrm{~nm}$, as expected from the blue colour (Fig. 4). The broad shoulder at $330 \mathrm{~nm}$ representing a type $3 \mathrm{Cu}$ signal was not detected clearly in the absorption spectrum of native laccase. Anaerobic treatment with a reducing agent, ascorbic acid, led to a decrease in absorbance in this region, showing that type $3 \mathrm{Cu}$ is present even though the signal is weak. Phlebia radiata laccase did not give the typical absorption maximum of type $3 \mathrm{Cu}$ at $330 \mathrm{~nm}$ and contains pyrroloquinoline quinone (PQQ) instead of copper as a cofactor (Karhunen et al., 1990). However, PQQ was not detected in P. ostreatus laccase using a hexanol extraction procedure (van der Meer et al., 1988).

As in the spectrum of Polyporus versicolor laccase (Vänngård, 1972), the EPR spectra of laccase I showed a superposition of type 1 and type 2 signals (Fig. 5). The parameters of the type $1 \mathrm{Cu}$ signal were $g_{\|}=2 \cdot 197$ and $A_{\|}=0.009 \mathrm{~cm}^{-1}$, and those of the type $3 \mathrm{Cu}$ signal $g_{\|}=2.263$ and $A_{\|}=0.0176 \mathrm{~cm}^{-1}$. These values closely resemble those of Polyporus versicolor $(2 \cdot 190$ and

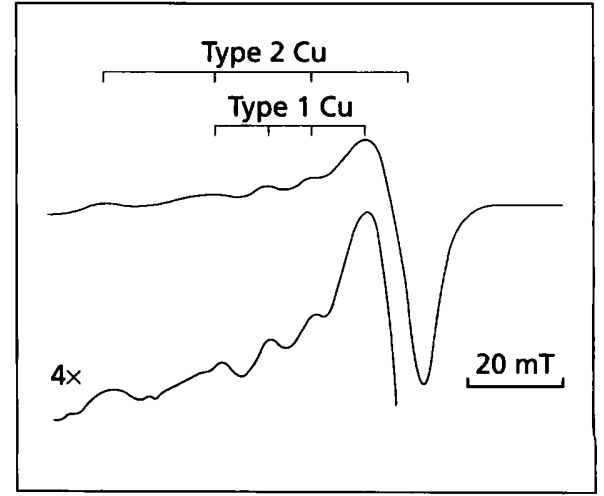

Fig. 5. X-band EPR spectra of $P$. ostreatus laccase I. Enzyme samples $(3.8 \mathrm{mg})$ were dissolved in $50 \mathrm{mM}$ sodium acetate buffer ( $\mathrm{pH}$ 5.0) and scanned as described in Methods.

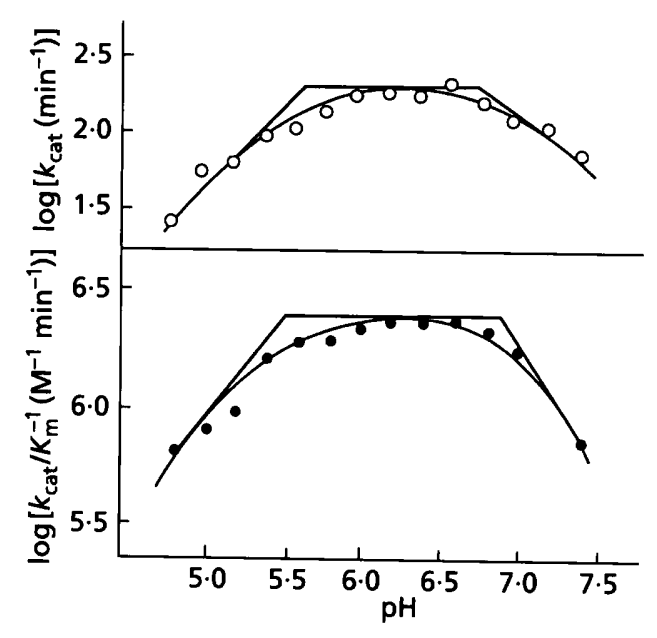

Fig. 6. $\mathrm{pH}$ profiles of the steady-state kinetic parameters $k_{\mathrm{cat}}$ and $k_{\text {cat }} J K_{m}$ for the oxidation of syringaldazine by $P$. ostreatus laccase $l$. Reaction mixtures contained various concentrations of syringaldazine buffered with $0.1 \mathrm{M}$ citrate $/ 0.2 \mathrm{M}$ disodium phosphate. Initial velocity was determined by measuring consumption of molecular oxygen.

$0.0090 \mathrm{~cm}^{-1}$, and 2.243 and $0.0194 \mathrm{~cm}^{-1}$, respectively; Vännegård, 1972) and of Pblebia radiata (2.19 and $0.009 \mathrm{~cm}^{-1}$, and 2.25 and $0.017 \mathrm{~cm}^{-1}$, respectively; Karhunen et al., 1990).

As judged from the colour, copper content, and absorption and EPR spectra, $P$. ostratus laccase $I$ is a coppercontaining protein like other fungal laccases.

\section{Effects of temperature and pH on enzyme activity}

The optimal temperature for laccase I activity under the standard assay conditions was $30-35^{\circ} \mathrm{C}$. The Arrhenius plot indicated an activation energy of $10.7 \mathrm{~kJ} \mathrm{~mol}^{-1}$ from $30-35^{\circ} \mathrm{C}$. The optimal $\mathrm{pH}$ for laccase activity was $6 \cdot 0-6.5$. As shown by the $\mathrm{pH}$ profiles of the steady-state kinetic parameters $k_{\text {cat }}$ and $k_{\text {cat }} / K_{\mathrm{m}}$ for syringaldazine (Fig. 6), two ionization groups with $\mathrm{p} K_{\mathrm{a}}$ values of $5 \cdot 60-5 \cdot 70$ and 
Table 2. Substrate specificity of laccase I from $P$. ostreatus

Reaction mixtures contained $0 \cdot 1 \mathrm{mM}$ substrate in $20 \mathrm{mM}$ sodium phosphate buffer ( $\mathrm{pH} 6.0$ ). Initial velocity was measured after the addition of $0.01 \mathrm{U}$ laccase I. Activity is expressed relative to that towards ferulic acid $\left(45 \cdot 4 \mathrm{nmol} \mathrm{O}_{2}\right.$ uptake $\left.(\mathrm{min})^{-1}\right)$, defined as $100 \%$

\begin{tabular}{|lc|}
\hline Substrate & $\begin{array}{c}\text { Relative } \\
\text { activity } \\
\mathbf{( \% )}\end{array}$ \\
\hline Ferulic acid & $100 \cdot 0$ \\
Syringic acid & $76 \cdot 2$ \\
Pyrogallol & $45 \cdot 7$ \\
Guaiacol & $33 \cdot 3$ \\
Vanillin & $19 \cdot 0$ \\
Gallic acid & $6 \cdot 2$ \\
Vanillic acid & $4 \cdot 8$ \\
p-Coumaric acid & $4 \cdot 3$ \\
Tyrosine & $1 \cdot 4$ \\
trans-Cinnamic acid & $0 \cdot 0$ \\
3,4-Dimethoxycinnamic acid & $0 \cdot 0$ \\
Veratryl alcohol & $0 \cdot 0$ \\
\hline
\end{tabular}

6.70-6.85 were observed. These two ionization groups may play an important role in the active site of laccase I as the ligand of copper metal.

\section{Substrate specificity}

Laccase I exhibited phenol oxidase activity towards various lignin-related compounds. As shown in Table 2, the enzyme had high affinity for phenolic compounds containing methoxyl and $p$-hydroxy groups directly attached to the benzene ring, but no affinity for nonphenolic compounds such as trans-cinnamic acid, 3,4dimethoxycinnamic acid and veratryl alcohol. Substrate specificity was thus similar to that of $P$. ostreatus peroxidase (Kang et al., 1993).

The $K_{\mathrm{m}}$ and $k_{\text {cat }}$ for ferulic acid were $48 \mu \mathrm{M}$ and $4 \cdot 10 \times 10^{3} \mathrm{nmol} \mathrm{O}$ uptake $\mathrm{min}^{-1}$ (nmol enzyme) ${ }^{-1}$ and for syringic acid were $89 \mu \mathrm{M}$ and $2.54 \times 10^{3} \mathrm{nmol} \mathrm{O}_{2}$ uptake $\min ^{-1}(\mathrm{nmol} \text { enzyme })^{-1}$.

\section{Single electron transfer}

The EPR spectrum presented in Fig. 7 shows that 3,5-dimethoxy-5-hydroxyacetophenone, a lignin-related compound, was oxidized to a phenoxy radical by laccase I. The EPR parameters of the phenoxy radical were determined as follows: $a_{\mathrm{OCH} 3}=14.36 \mathrm{mT}$ ( 6 eq. protons), $a_{\mathrm{H} \text { (meta) }}=14.36 \mathrm{mT}$ (2 eq. protons) and $a_{\mathrm{CH} 3}=3.40 \mathrm{mT}$ (3 eq. protons). It was very similar to the EPR spectrum obtained from Phanerochaete chrysosporium lignin peroxidase except that the latter showed extra peaks due to a secondary radical signal (Odier $e t$ al., 1988). The phenoxy radical from laccase I-catalysed oxidation of 3,5dimethoxy-5-hydroxyacetophenone may be formed via

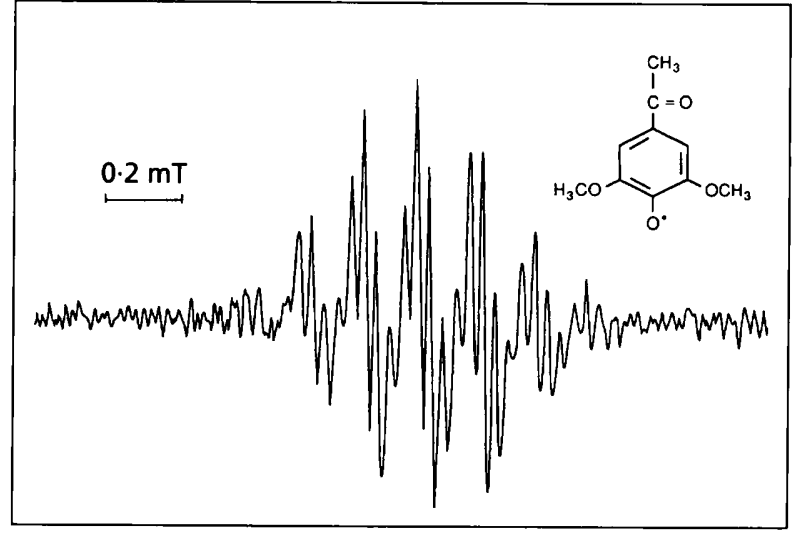

Fig. 7. EPR spectrum of the phenoxy radical produced by the action of laccase I on 3,5-dimethoxy-4-hydroxyacetophenone. The reaction conditions are described in Methods.

deprotonation of the $p$-hydroxy group attached to the benzene ring.

\section{ACKNOWLEDGEMENTS}

This work was supported by Korea Science and Engineering Foundation (KOSEF) research grant for SRC (Research Center for Molecular Microbiology, Seoul National University).

\section{REFERENCES}

Agosin, E., Daudin, J. J. \& Odier, E. (1985). Screening of white-rot fungi on $\left[{ }^{14} \mathrm{C}\right]$ lignin-labelled and $\left[{ }^{14} \mathrm{C}\right]$ whole-labelled wheat straw. Appl Microbiol Biotechnol 22, 132-138.

Brumby, P. E. \& Massey, V. (1967). Copper determinations. Methods Enzymol 10, 471-474.

De Vries, O. M. H., Kooistra, W. H. C. F. \& Wessels, J. G. H. (1986). Formation of an extracellular laccase by a Schizopbyllum commune dikaryon. J Gen Microbiol 132, 2817-2826.

Dubois, M., Gilles, K. A., Hamilton, J. K., Robers, P. A. \& Smith, F. (1956). Colorimetric method for determination of sugars and related substrates. Anal Chem 28, 350-356.

Eriksson, K.-E. L., Blanchette, R. A. \& Ander, P. (1990). Biochemistry of lignin degradation. In Microbial and Enzymatic Degradation of Wood and Wood Components, pp. 253-307. Berlin: Springer-Verlag.

Froehner, S. C. \& Eriksson, K.-E. L. (1974). Purification and properties of Neurospora crassa laccase. J Bacteriol 120, 458-465.

Germann, U. A., Muller, G., Hunziker, P. E. \& Lerch, K. (1988). Characterization of two allelic forms of Neurospora crassa laccase. $J$ Biol Chem 263, 885-896.

Jeong, I.-B., Youn, H.-D., Maeng, J.-S., Kang, S.-O., Hah, Y. C., Jeong, G., Choi, H. T. \& Kim, J.-H. (1992). Characterization of laccase excreted from Lentinus edodes. Korean J Microbiol 30, 252-259.

Kang, S.-O., Shin, K.-S., Han, Y.-H., Youn, H.-D. \& Hah, Y. C. (1993). Purification and characterisation of an extracellular peroxidase from white-rot fungus Pleurotus ostreatus. Biochim Biophys Acta 1163, 158-164.

Karhunen, E., Niku-Paavola, M.-L., Viikari, L., Haltia, T., van der Meer, R. A. \& Duine, J. A. (1990). A novel combination of 
prosthetic groups in a fungal laccase: PQQ and two copper atoms. FEBS Lett 267, 6-8.

Kim, K.-J., Shin, K.-S. \& Hong, S.-W. (1986). Induction of extracellular polyphenol oxidase from two white-rot fungi. Korean J Mycol 14, 43-47.

Kim, K.-J., Maeng, J.-S., Shin, K.-S., Kang, S.-O., Hah, Y. C. \& Hong, S.-W. (1987). Characterization of laccase from Pleurotus ostreatus. Korean J Microbiol 25, 148-156.

Kirk, T. K. \& Farrell, R. L. (1987). Enzymatic combustion: the microbial degradation of lignin. Annu Rev Microbiol 41, 465-505.

Kosima, Y., Tsukuda, Y., Kawai, Y., Tsukamoto, A., Sugiura, J., Sakaido, M. \& Kita, Y. (1990). Cloning, sequence analysis, and expression of ligninolytic phenoloxidase genes of the white-rot basidiomycete Coriolus hirsutus. J Biol Chem 265, 15224-15230.

Laemmli, U. K. (1970). Cleavage of structural proteins during the assembly of the head of bacteriophage T4. Nature 227, 680-685.

Leonowicz, A. \& Grzywnowicz, K. (1981). Quantitative estimation of laccase forms in some white-rot fungi using syringaldazine as a substrate. Enzyme Microb Technol 3, 55-58.

van der Meer, R. A., Jongejan, J. A. \& Duine, J. A. (1988). Identification and quantification of PQQ. In PQQ and Quinoproteins, pp. 111-122. Edited by J. A. Jongejan \& J. A. Duine. Dordrecht: Kluwer Academic Publishers.

Mondovi, B. \& Avigliano, L. (1984). Ascorbate oxidase. In Copper Proteins and Copper Enzymes, vol. III, pp. 101-118. Edited by R. Lontie. Boca Raton: CRC Press.

Niku-Paavola, M.-L., Karhunen, E., Salola, P. \& Raunio, V. (1988). Ligninolytic enzymes of the white-rot fungus Pblebia radiata. Biocbem J 254, 877-884.

Odier, E., Mozuch, M. D., Kalyanaraman, B. \& Kirk, T. K. (1988). Ligninase-mediated phenoxy radical formation and polymerization unaffected by cellobiose:quinone oxidoreductase. Biocbimie $\mathbf{7 0}$, 847-852.

Rehman, A. U. \& Thurston, C. F. (1992). Purification of laccase I from Armillaria mellea. J Gen Microbiol 138, 1251-1257.

Reinhammar, B. (1984). Laccase. In Copper Proteins and Copper Enzymes, vol. III, pp. 1-35. Edited by R. Lontie. Boca Raton: CRC Press.

Saloheimo, M., Niku-Paavola, M.-L. \& Knowles, J. K. C. (1991). Isolation and structural analysis of the laccase gene from the lignindegrading fungus Pblebia radiata. J Gen Microbiol 137, 1537-1544.

Sannia, G., Giardina, P., Luna, M., Rossi, M. \& Buonocore, V. (1986). Laccase from Pleurotus ostreatus. Biotechnol Lett 8, 797-800.

Sannia, G., Limongi, P., Cocca, E., Buonocore, F., Nitti, G. \& Giardina, P. (1991). Purification and characterization of a veratryl alcohol oxidase enzyme from the lignin degrading basidiomycete Pleurotus ostreatus. Biochim Biophys Acta 1073, 114-119.

Shin, K.-S., Youn, H.-D., Han, Y.-H., Kang, S.-O. \& Hah, Y. C. (1993). Purification and characterisation of D-glucose oxidase from white-rot fungus Pleurotus ostreatus. Eur J Biochem 215, 747-752.

Towbin, H., Staehelin, T. \& Gordon, J. (1979). Electrophoretic transfer of proteins from polyacrylamide gels to nitrocellulose sheets: procedure and some applications. Proc Natl Acad Sci USA 76, 4350-4354.

Vänngård, T. (1972). Copper proteins. In Biological Applications of Electron Spin Resonance, pp. 411-447. Edited by H. M. Swartz, J. R. Bolton \& D. C. Borg. New York: Wiley.

Wood, D. A. (1980). Production, purification and properties of extracellular laccase of Agaricus bisporus. J Gen Microbiol 117, $327-338$.

Received 11 August 1994; accepted 20 October 1994. 